\title{
Impact of Capital Inflows on Economic Growth of Developing Countries
}

\author{
Chigbu Ezeji E. \\ Department of Financial Management Technology, Federal University of Technology, Owerri, Nigeria \\ Ubah Chijindu Promise \\ Department of Financial Management Technology, Federal University of Technology, Owerri, Nigeria \\ Chigbu Uzoamaka S. \\ Department of Banking and Finance, Imo State University, Owerri, Nigeria
}

\begin{abstract}
This study examines the impact of capital inflows on economic growth of developing economies; the case of Nigeria, Ghana and India from 1986-2012. This is necessitated by the doubts being raised as whether the huge inflows of foreign capital in developing economies over the years have transmitted to real economic growth. Augmented Dickey Fuller unit root test was employed to evaluate the stationarity of the data, while Johansen Co-integration was used to estimate the long-run equilibrium relationship among the variables. The casual relationship was tested using Granger Causality, and Ordinary Least Square method was used to estimate the model. The findings reveals that capital inflows have significant impact on the economic growth of the three countries. In Nigeria and Ghana, foreign direct and portfolio investment as well as foreign borrowings have significant and positive impact on economic growth. Workers' remittances significantly and positively related to the economic growth of the three countries. The enabling environment should be created in the developing countries to encourage more inflow of foreign investments and workers remittances. This will help in closing the savings-investment gap and encourage economic growth in these countries. The study signifies that capital inflows is indispensable in closing the savings-investment gap required for economic growth of developing countries.
\end{abstract}

Keywords: Foreign capital inflows, foreign direct investments, foreign portfolio investment, foreign aids, workers' remittances, foreign borrowings and economic growth

\section{Introduction}

Capital inflows is the movement into a country of capital resources for the purpose of investment, trade or business production. It has significant role for every national economy, regardless of its level of development. For the developed countries, it is necessary to support sustainable development while for the developing economies, it is used to increase accumulation and rate of investments to create conditions for accelerated economic growth. For the transition countries, it is useful to carry out the reforms necessary to cross to open economy (Edwards, 2004), to cross the past long term problems and to create conditions for stable and continuous growth of GDP (Razin, 2001), as well as integration in the world economy (Boskovska, 2006). However, to realize the potentials that exist in the developing countries, foreign capital is indispensable. Capital inflow can help developing countries in economic development by furnishing them with necessary capital and technology, which will be used to harness their local resources. Capital inflows contribute in filling the resource gap in countries where domestic savings are inadequate to finance the required investment. Capital inflows allow the recipient country to invest and consume more than it produces when the marginal productivity of capital within its borders is higher than in the capital-rich regions of the world. As the economy becomes more open and integrated with the rest of the world, capital inflows will contribute significantly to the transformation of the developing economy (Levine, 2001). Added to this, capital inflows are necessary for macroeconomic stability as they affect a wide range of macroeconomic variables such as exchange rates, interest rates, foreign exchange reserves, domestic monetary conditions as well as savings and investments.

The Harrod-Domar Model suggests that the savings as well as investment rates must be between $18 \%$ - $20 \%$ to sustain the 6\% growth of GDP (Jhingan, 2005). However, mostly less developed countries are entrapped by the vicious circle of poverty. They already lack the capital resources and the incomes of the people are very low. Because of low incomes, the savings ratios also remain low, resulting in low investment levels. At the same time, due to low income, the taxable capacity remains lower, i.e. government earnings also remain low. In such situations, the less developed countries have to face savings - investment deficit as well as the deficit in balance of payments. Thus, these gaps can be filled by foreign capital inflows in the form of direct and portfolio investment, aid, foreign borrowing etc. 
However, the practical impact of foreign capital inflows in closing these gaps by achieving growth and development of developing countries have not adequately materialized and this has questioned the place of capital inflows in developing countries.

\section{Literature review}

There exist two strands of literature on the role of foreign capital inflows on economic growth. The first proponents assert that overseas capital inflow is necessary and sufficient for economic growth in the less developed countries (Gupta, 1970). They claim that there exists a positive relationship between capital inflows and economic growth because it complements domestic resources and supplements domestic savings. Furthermore, foreign inflows assists in closing the foreign exchange gap, provides access to modern technology and managerial skills, and allow for easier access to foreign market (Over, 1975). The second proponents are related to the emergence of the view that external capital exerts significant negative effects on the economic growth of recipient countries. According to this view, foreign capital is fully consumed and substitutes rather than compliments domestic resources. Furthermore, foreign inflows assist to import inappropriate technology, distorts the domestic income distribution, and encourages a bigger, inefficient and corrupt government in developing countries (Griffin and Enos, 1970).

In reaction to the above, the issue of poor economic performance and growth of developing economies have become so worrisome that it has called for a wide range of researches and discussions. Capital inflow is identified in the literature both theoretically and empirically as an important catalyst for the required growth. From the foregoing, it appears to be ineffective in salvaging the developing economies despite the huge inflows of capital, as there is significant evidence of abject poverty, high rate of unemployment, decaying infrastructure, high mortality rate among others World Bank (2013). It is against this backdrop that this study is designed to find how these inflows have over the years contributed to the growth and development of these economies.

\subsection{Theoretical framework}

There are a number of theories explaining foreign capital investment. Except for the MacDougall-Kemp hypothesis, FDI theories are primarily based on imperfect market conditions while a few among them are based on imperfect capital market. Others consider non-economic factors. Still others explained the emergence of Multi-National Corporations, (MNCs) exclusively among developing countries.

\subsubsection{MacDougall-Kemp hypothesis}

One of the earliest theories of capital inflows was developed by MacDougall (1958) and subsequently elaborated by Kemp (1964). According to the hypothesis, assuming a two-country model - one being the investing country and the other being the host country, and the price of capital being equal to its marginal productivity, capital moves freely from a capital abundant country to a capital scarce country and in this way the marginal productivity of capital tends to equalize between the two countries. This leads to improvement in efficiency in the use of resources that leads ultimately to an increase in welfare. Despite the fact that the output in the investing country decreases in the wake of foreign investment outflow, national income does not fall in so far as the country receives returns on capital invested abroad, which is equivalent to marginal productivity of capital times the amount of foreign investment. So long as the income from foreign investment is greater than the loss of output, the investing country continues to invest abroad because it enjoys greater national income than prior to foreign investment. The host country too witnesses increase in national income as a sequel to greater magnitude of investment, which is not possible in the absence of foreign investment inflow.

\subsubsection{Industrial organization theory}

The industrial organization theory is based on an oligopolistic or imperfect market in which the investing firm operates. Market imperfections arise in many cases, such as product differentiation, marketing skills, proprietary technology, managerial skills, better access to capital, economies of scale, government-imposed market distortions, etc. Such advantages confer on Multi-National Companies an edge over their competitors in foreign locations and thus, help compensate the additional cost of operating in an unfamiliar environment. Stephen Hymer, (1976), propounded one of the earliest theories based on the assumptions of an imperfect market. To Hymer, a multinational firm is a typical oligopolistic firm that possesses some sort of superiority and that looks for control in an imperfect market with a view to maximizing profits. Despite the fact that the international firm is posted disadvantageously in a foreign host country where it has not intimate knowledge of language, culture, legal systems and consumers' preference, it possesses certain specific advantages that outweigh the disadvantages. The firm-specific advantages in Hymer's view are mainly the technological advantages that help the firm to produce a new product different from the existing one. It is related, in fact, to the possession of knowledge, which helps in developing special marketing skills, superior organizational and management set-up, and improved processing. What is significant in this theory is that these advantages are transmitted more effectively from one unit to the other irrespective of their geographical distance. Since the market is imperfect, rival firms do not avail of the technological advantage. International firm harvests huge profits. Caves (1971) feels that 
firm-specific advantages are transmitted more effectively if the firm participates effectively in the production in the host country than through other ways such as export or licensing agreements.

\subsubsection{Location-specific theory}

Hood and Young, (1979) stress upon the location-specific advantages. They argue that since real wage cost varies among countries, firms with low cost technology move to low wage countries. Again, in some countries, trade barriers are created to restrict import. Multi-National Corporations (MNCs) invest in such countries in order to start manufacturing there and evade trade barriers. It is sometimes the availability of cheap and abundant raw material that encourages the MNCs to invest in the country with abundant raw material.

\subsubsection{Eclectic paradigm}

Dunning's eclectic paradigm is a combination of the major imperfect market-based theories of capital inflows, i.e. industrial organization theory, internalization theory and location theory. It postulates that, at any given time, the stock of foreign assets owned by a multinational firm is determined by a combination of firm specific or ownership advantage, $(\mathrm{O})$ the extent of location bound endowments, $(\mathrm{L})$ and the extent to which these advantages are marketed within the various units of the firm (I). Dunning is conscious that configuration of the O-L-I advantages varies from one country to the other and from one activity to the other. Foreign investment will be greater where the configuration is more pronounced. Again, he introduces a "dynamized add-on" variable to his theory. This is nothing but a variable of strategic change, which may be either autonomous or a strategy induced change. International production during a particular period would be the sum of the strategic responses of the firm to the past configuration of O-L-I and to changes in such configuration as a sequel to exogenous and endogenous changes in environment. The example of autonomous change in strategy may be that a firm makes foreign investment more in innovatory activities because of greater O-advantage, or it invests more in a particular country because of L-advantage or it adopts a different marketing strategy depending upon the greater amount of I-advantage. Similarly, the strategy-induced change may be evident from the fact that a market seeing investment has a different O-L-I configuration from that of a resource based investment. Ultimately, the varying configuration shapes the direction and the pattern of FDI (Dunning, 1980, 1993).

\subsection{Empirical reviews}

The role of foreign capital inflow in economic development and growth remains contentious in economics literature. Some studies prove that it has its positive impact on the economic development empirically, while others proved that it has negative effects as well. Here we reviewed the works of some of these scholars and the corresponding findings made in each case.

Narayan (2013) examined the casual relationship between foreign capital inflows and economic growth in India. Using the pair-wise Granger causality test (1969), he specifically examines causal relationship between foreign capital inflows and economic growth in India. The important observations emerge from pair-wise Granger causality test, which shows there is the long-run equilibrium relationships exist between the following pairs of variables viz., economic growth and Foreign Direct Investment (FDI), economic growth and Foreign Portfolio Investment (FPI).

Aurangeb and Haq, (2012) investigated the impact of foreign capital inflows on economic growth of Pakistan. The data used in this study were collected from the period of 1981 to 2010 . Unit root test confirms the stationary of all variables at first difference. The multiple regression analysis technique was used to identify the significance of different factors. Results indicate that the all three independent variables are having positive and significant relationship with economic growth (GDP). The Granger-Causality test confirms the bidirectional relationship between remittances and external debt, gross domestic product and external debt, foreign direct investment and external debt, and foreign direct investment and remittances. On the other side, the study found unidirectional relationship from gross domestic product to foreign direct investment. It is concluded that the foreign capital inflows are very important for the growth of any economy.

Obiechina and Ukeje (2013) examined the impact of capital flows (foreign direct investment), exchange rate, export and trade openness on economic growth of Nigeria as well as the causal long-run relationship among the variables, using time series data from 1970 - 2010. The unit root test confirmed the series to be stationary at I (1), while the Johansen Co-integration test suggested the existence of at least one Co-integration vector among the variables. Using Engle-Granger 2-Step procedure, it was observed that all the variables, except the FDI are statistically significant and influence economic growth in the short-run dynamic equilibrium model. Exogeneity test confirmed that fdi has weak exogeneity with economic growth. In addition, the Pairwise Granger causality revealed the existence of uni-directional causality between economic growth and fdi, and uni-directional and bi-directional causality among some of the variables.

Odhiambo, (2011) studied the dynamic causal relationship between financial deepening and economic growth in Tanzania using a multivariate model. The study included foreign capital inflows as an intermittent variable between financial deepening and economic growth, thereby creating a simple tri-variate model. Using the newly introduced ARDL-bounds testing procedure, the study finds a distinct unidirectional casual flow from economic growth to 
financial depth in Tanzania. This applies irrespective of whether the causality is estimated in the short run or in the long-run. Other results show that there is a bi-directional causality between financial development and foreign capital inflows, and a prima-facie unidirectional causality from foreign capital inflows to economic growth. The study, therefore, concludes that financial development in Tanzania follows growth, irrespective of whether the causality is estimated in a static or dynamic formulation.

In 2011, Adeniyi, Omisakin, Egwaikhide and Oyinlola, examined the causal linkage between foreign direct investment (FDI) and economic growth - in Cote' d'Ivoire, Gambia, Ghana, Nigeria and Sierra Leone - with financial development accounted for over the period 1970-2005 within a trivariate framework which applies Granger causality tests in a vector error correction (VEC) setting. Three alternative measures of financial sector development - total liquid liabilities, total banking sector credit and credit to the private sector - were employed to capture different ramifications of financial intermediation. The results support the view that the extent of financial sophistication matters for the benefits of foreign direct investment to register on economic growth in Ghana, Gambia and Sierra Leone depending on the financial indicator used. Nigeria, on the other hand, displays no evidence of any short- or long-run causal flow from FDI to growth with financial deepening accompanying.

Olusanya (2013) takes a look at the impact of Foreign Direct Investment inflow and economic growth in a pre and post deregulated Nigerian economy, a Granger causality test was use as the estimated technique between 1970 - 2010. However, the analysis de-aggregates the economy into three period; 1970 to 1986,1986 to 2010 and 1970 to 2010 , to test the causality between foreign direct investment inflow (FDI) and economic growth (GDP). However, the result of the causality test shows that there is causality relationship in the pre-deregulation era that is (1970-1986) from economic growth (GDP) to foreign direct investment inflow (FDI) which means GDP causes FDI, but there is no causality relationship in the post-deregulation era that is (1986-2010) between economic growth (GDP) and foreign direct investment inflow (FDI) which means GDP causes FDI. However, between 1970 to 2010 it shows that is causality relationship between economic growth (GDP) and foreign direct investment inflow (FDI) that is economic growth drive foreign direct investment inflow into the country and vice versa.

Umoh, Jacob and Chuku, (2012) proposed that there is endogeniety i.e., bi-directional relationship between FDI and economic growth in Nigeria. Single and simultaneous equation systems are employed to examine if there is any sort of feedback relationship between FDI and economic growth in Nigeria. The results obtained show that FDI and economic growth are jointly determined in Nigeria and there is positive feedback from FDI to growth and from growth to FDI.

Fambon (2013) capture the impact of foreign capital inflows (which include foreign aid and foreign direct investment) on economic growth in Cameroon. Using the autoregressive distributive lag approach to Co-integration and time-series data for the period 1980-2008, the results of the study indicate that the domestic capital stock and foreign direct investment have positive and significant impacts on economic growth in the short and long terms, while the impact of the labour force on growth was significantly negative in both terms, a result that may be attributable to the fact that Cameroon is a developing country with an unlimited supply of labour whose increase has a detrimental effect on the country's growth.

Ekeocha, Malaolu and Oduh, (2012) ascertained the long run determinants of foreign portfolio investment (FPI) in Nigeria such that appropriate policies will be pursued to attract same in the long run. FPI has grown recently in proportion relative to other types of capital inflows to Nigeria before the wake of global financial crisis. Incidentally, there is no empirical regularity regarding the determinants of FPI. This study tries to add to the stock of knowledge by modelling the long-run determinants of FPI in Nigeria over the period of 1981-2010 converted into quarterly series. The variables considered are, market capitalization, real exchange rate, real interest rate, real gross domestic product and trade openness. The study applies time series analysis specifically the finite distributed lag model and discovers that FPI has a positive long-run relationship with market capitalization, and trade openness in Nigeria.

Lensink and Morrissey, (2001) examined the effect of aid on economy by controlling aid uncertainty for a number of developing aid recipient countries. The study posits that the impact of aid on growth depends fundamentally on the effect of aid on the level and efficacy of investment. The study showed that aid uncertainty is consistently and significantly have negative effect on growth and that controlling for uncertainty has a negative robust effect on growth via the level of investment. Karras, (2006) examined the relationship between foreign aid and growth in per capita GDP for the period 1960-1997 for a sample of 71 aid-receiving developing countries.

The study showed that the effect of foreign aid on economic growth is positive, permanent, significant and sizable, while Chatterjee and Turnosky (2005) investigated the link between foreign aid and economic growth and welfare in a small open economy. The study found external transfer to impinge on the recipient's macroeconomic performance by affecting resource allocation decisions and relative prices. The study further stressed that endogeneity of the labourleisure choice and the adjustment of the real wage rate plays a crucial role in the propagation of foreign aid shocks and that another crucial determinant of the efficacy of foreign aid is externalities associated with the public good that aid helps public finance. The study showed further that transitional adjustment to a foreign aid shock is dependent crucially on the elasticity of substitution in production and the relative importance of the labor-leisure choice utility. 
Ezeabasili, Isu and Mojekwu (2011) investigated the relationship between Nigeria's external debt and economic growth, between 1975 and 2006. The choice of period was guided by data availability and the escalation of Nigeria's external debt. He found that external debt has negative relationship with economic growth in Nigeria. For example, a one per cent increase in external debt resulted in a decrease of 0.027 per cent in Gross Domestic Product, while a 1 per cent increase in total debt service resulted to 0.034 per cent (decrease) in Gross Domestic Product. These relationships were both found to be significant at the ten per cent level. In addition, the pairwise Granger Causality test revealed that uni-directional causality exists between external debt service payment and economic growth at the 10 percent level of significance. In addition, external debt was found to granger cause external debt service payment at the 1 percent level of significance, while statistical interdependence was however found between external debt and economic growth.

\section{Methodology}

This session explores the techniques and procedures applied in the collection of data and tools for statistical analysis.

\subsection{Source and collection of data}

The set of time series data used in this study were collected from secondary sources. The data include real gross domestic product proxied for economic growth, while capital inflows include foreign direct and portfolio investment, foreign aids, workers' remittances and foreign borrowings, collected for the period of 1986 to 2012. The data were obtained from World Bank databank economic indicators. Meanwhile the data for foreign direct and foreign portfolio investment were summed together as one variable.

\subsection{Model specification}

In this study, we employed the Ordinary Least Square method to develop a model on the relationship between capital inflows and economic growth of the developing economies selected. The functional and parametric models is as stated below:

$\operatorname{RGDP}_{\mathrm{t}}=\mathrm{f}\left(\mathrm{FDPI}_{\mathrm{t}}, \mathrm{FA}_{\mathrm{t}}, \mathrm{WRT}_{\mathrm{t}}, \mathrm{FB}_{\mathrm{t}}, \mathrm{U}_{\mathrm{t}}\right) \ldots \ldots \ldots \ldots \ldots \ldots \ldots \ldots \ldots \ldots \ldots$
$\mathrm{RGDP}_{\mathrm{t}}=\beta_{0}+\beta_{1} \mathrm{FDPI}_{\mathrm{t}}+\beta_{2} \mathrm{FA}_{\mathrm{t}}+\beta_{3} \mathrm{WRT}_{\mathrm{t}}+\beta_{4} \mathrm{FB}_{\mathrm{t}}+\ldots+\mathrm{U}_{\mathrm{t}}$

Where RGDP is real gross domestic product proxied for economic growth;

FDPI is foreign direct and portfolio investment;

FA is foreign aids;

WRT is workers' remittances;

FB is foreign borrowings;

$\mathrm{U}_{\mathrm{t}}$ are the stochastic variables.

The a priori signs are $\beta_{1}=\beta_{2}=\beta_{3}=\beta_{4}>0$.

In other to actualize the aforementioned hypothetical assumptions, we employed the following models and tests to this effect. Regression analysis as stated above was used to specify the model. The time series properties of the variables were examined using Augmented Dickey Fuller, (ADF) unit root test, the long-run relationship among the variables was tested using the Johansen co-integration test, while the Granger causality test was applied to establish if there is a causal relationship between variables.

\section{Results of data analysis}

\subsubsection{Augmented Dickey-Fuller unit root test (Nigeria)}

It had been shown in econometric studies that most macroeconomic time series are not stationary at levels (Engle and Granger, 1987). This implies that most ordinary least squares (OLS) regressions that are carried out at levels may not be reliable. Giving this knowledge, testing for stationarity of variables to obtain a more reliable result becomes very essential. Augmented Dickey-Fuller unit root (ADF) test was used to examine the properties of the time series data. The test revealed that at 5\% critical values, Real Gross Domestic Product and Workers Remittances are stationary at levels with the probability of 0.0000 respectively as shown in Table 4.1. At first differencing, Foreign Direct and Portfolio Investment, Foreign Aids and Foreign Borrowing are stationary with the probability value of $0.0008,0.0005$ and 0.0020 respectively. 
Chigbu Ezeji E., Ubah Chijindu Promise, Chigbu Uzoamaka S.

Impact of Capital Inflows on Economic Growth of Developing Countries

Table 4.1: Augmented Dickey-Fuller Unit Root Test

\begin{tabular}{|c|c|c|c|c|c|}
\hline Variables & ADF at Levels & $\begin{array}{c}\text { ADF Test } \\
\text { Statistic }\end{array}$ & $\begin{array}{c}\text { Prob. } \\
\text { Values }\end{array}$ & $\begin{array}{c}\text { 5\% Test Critical } \\
\text { Values }\end{array}$ & Decisions \\
\hline RGDP & 3.1735 & 3.1735 & 0.0000 & -2.9810 & $\mathrm{I}(0)$ \\
\hline FDPI & 0.9264 & -4.8319 & 0.0008 & -2.9919 & $\mathrm{I}(1)$ \\
\hline FA & -2.7724 & -5.0939 & 0.0005 & -2.9981 & $\mathrm{I}(1)$ \\
\hline WRT & 4.3207 & 4.3207 & 0.0000 & -2.9981 & $\mathrm{I}(0)$ \\
\hline FB & -0.5687 & -4.4639 & 0.0020 & -2.9981 & $\mathrm{I}(1)$ \\
\hline
\end{tabular}

\subsubsection{Johansen Co-integration test}

When a linear combination of variables that are I (1) produces a stationary series, then the variables may be cointegrated. This means that a long-run relationship may exist among them, which connotes that they may wander from one another in the short-run but in the long run they will move together (Pesaran and Smith 2001). To establish whether long-run relationship exists among the endogenous series, Co-integration test using Johansen's multivariate method was employed.

\section{Table 4.2: Johansen Co-integration Test}

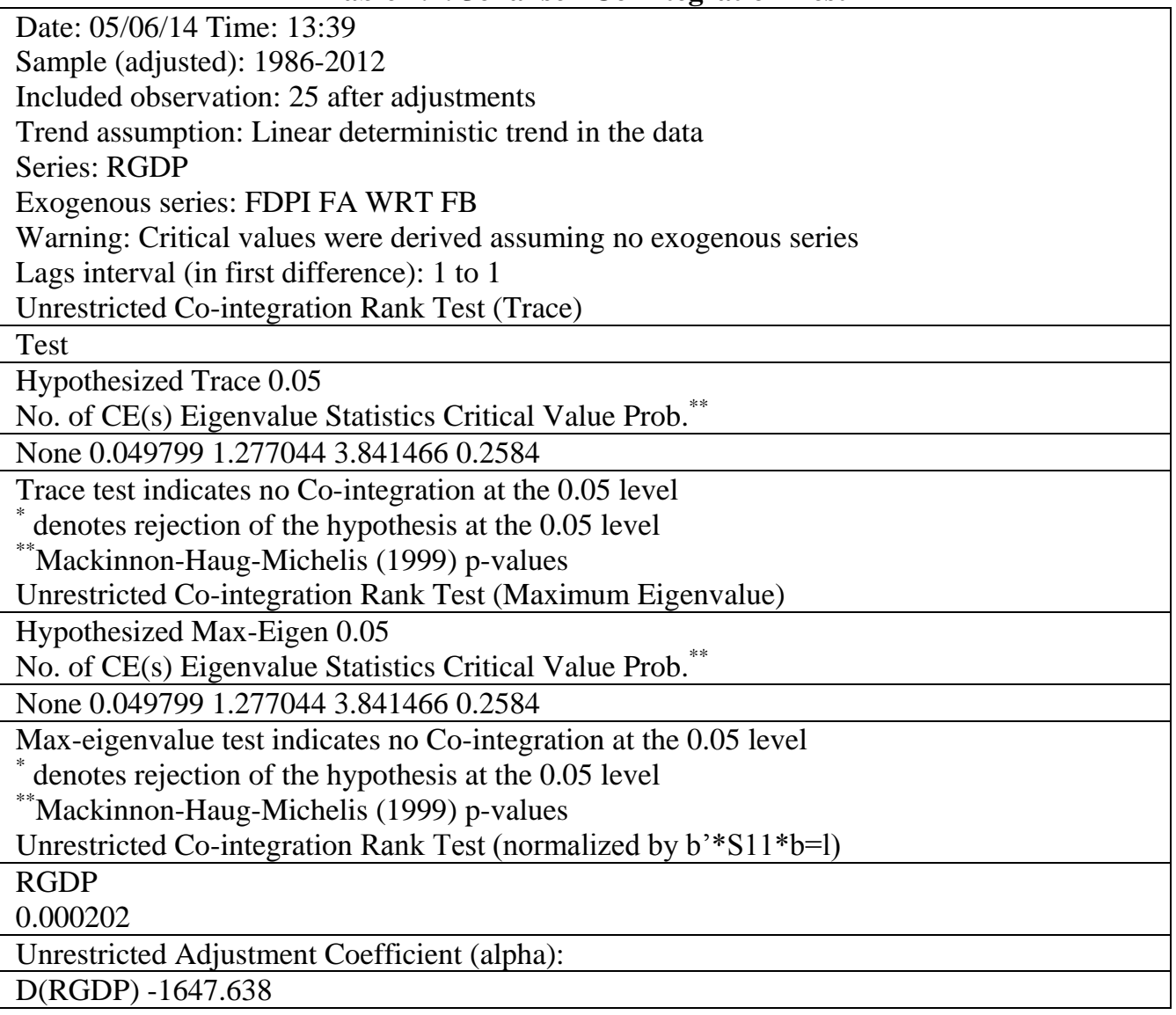

Table 4.2 showed that at $5 \%$ critical value (3.841466) is greater than the Trace Statistic and Maximum Eigenvalue Statistic (1.277044) and probability values of 0.2584 respectively without a co-integrating equation. This is an indication that the variables are not co-integrated in the long run, necessitating the acceptance of the null hypothesis of no co-integration.

\subsubsection{Granger causality test}

The Granger Causality approach to the problem of whether $\mathrm{x}$ causes $\mathrm{y}$ is to see how much of the current $\mathrm{y}$ can be explained by past values of $\mathrm{x}$ and then to see whether adding lagged values of $\mathrm{x}$ can improve the explanation. A variable granger cause another if the F-statistic is significant at $\mathrm{p}$-value of $5 \%$ or less 
Table 4.3: Granger Causality Test

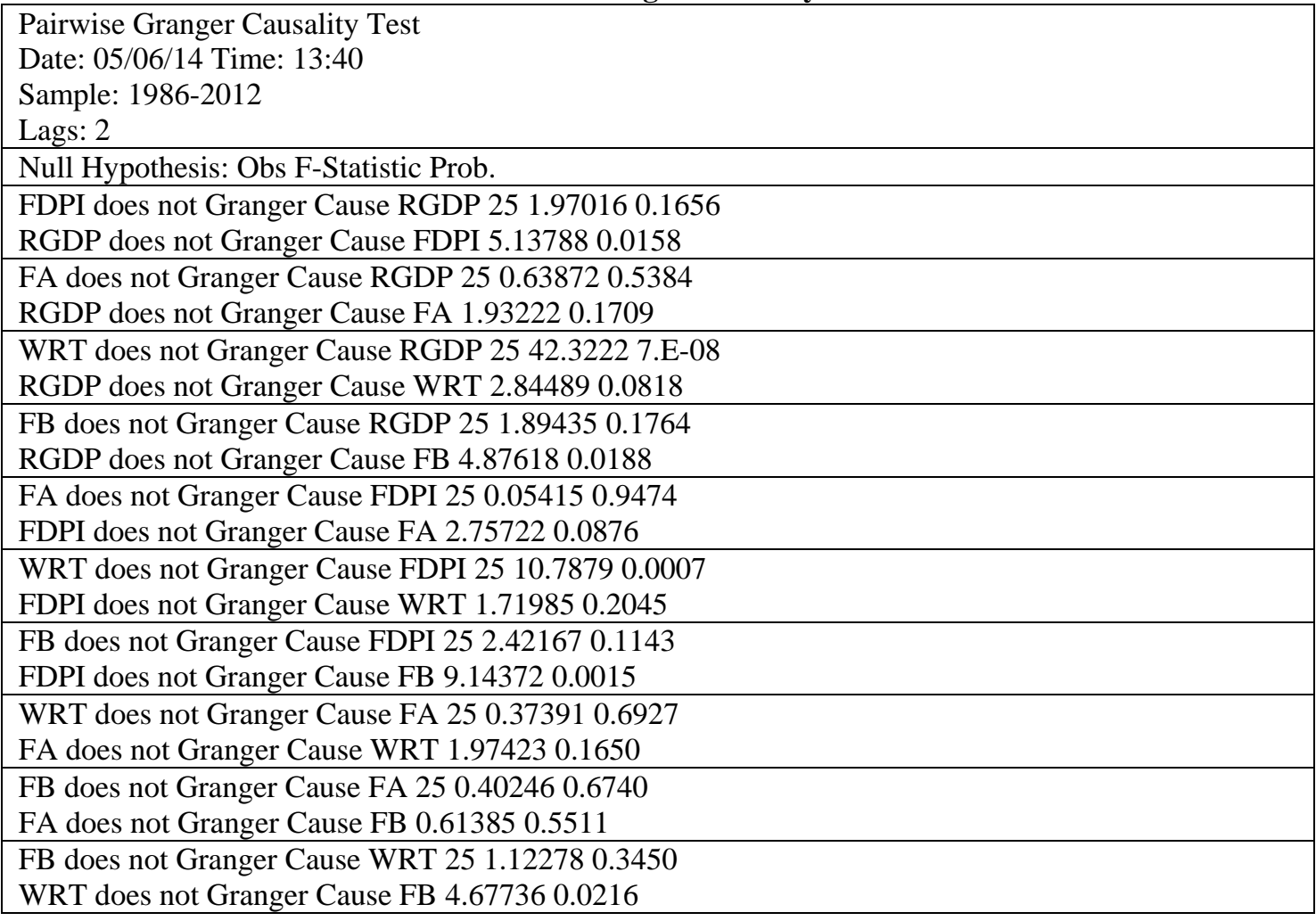

According to Table 4.3, there are no bi-directional causal relationships among the variables. However, uni-directional causal relationships are seen from Real Gross Domestic Relationship to Foreign Direct and Portfolio Investment, Workers Remittances to Real Gross Domestic Product, Real Gross Domestic Product to Foreign Borrowing, Workers Remittances to Foreign Direct and Portfolio Investment, Foreign Direct and Portfolio Investment to Foreign Borrowing and from Workers Remittances to Foreign Borrowing. More so, there are no causation between Foreign Aids and Real Gross Domestic Product, Foreign Aids and Foreign Direct and Portfolio Investment, Workers Remittances and Foreign Aids and between Foreign Borrowing and Foreign Aids respectively.

\section{Table 4.4: Results of Regression Analysis}

Dependent Variable: RGDP

Method: Least Squares

Date: 05/06/14 Time: 11:01

Sample: 1986-2012

Included observations: 27

\begin{tabular}{lllll}
\hline \hline Variable & Coefficient & Std. Error & t-Statistic & Prob. \\
\hline \hline C & 11105.24 & 16555.83 & 0.670775 & 0.5093 \\
FDPI & 4.488032 & 1.356111 & 3.309487 & 0.0035 \\
FA & -1.490644 & 0.991571 & -1.503316 & 0.1470 \\
WRT & 5.421621 & 1.084264 & 5.000277 & 0.0001 \\
FB & 1.770741 & 0.524707 & 3.374725 & 0.0027 \\
\hline \hline R-squared & 0.942735 & Mean dependent var & 93765.34 \\
Adjusted R-squared & 0.932324 & S.D. dependent var & 36591.33 \\
S.E. of regression & 9519.124 & Akaike info criterion & 21.32557 \\
Sum squared resid & $1.99 E+09$ & Schwarz criterion & 21.56554 \\
Log likelihood & -282.8952 & Hannan-Quinn criter. & 21.39692 \\
F-statistic & 90.54523 & Durbin-Watson stat & 1.362664 \\
Prob(F-statistic) & 0.000000 & & & \\
\hline \hline
\end{tabular}

Four explanatory variables were regressed against the dependent variable - Real Gross Domestic Product, the model is as stated below: 


$$
\mathrm{RGDP}_{\mathrm{t}}=11105.24+4.488 \mathrm{FDPI}-1.491 \mathrm{FA}+5.421 \mathrm{WRT}+1.771 \mathrm{FB} .
$$

(0.5093) (3.3095) (-1.5033) (5.0003) (3.3747)

$N B$ : the $t$-values are in parentheses

The result of the regression revealed one million Dollar increase in Real Gross Domestic Product will attract 4.488 million dollars foreign direct and portfolio investment to Nigeria, 1.491 million Dollar reduction in Foreign Aids, 5.421 million Dollars increase in workers remittances and 1.771 million Dollars increase in federal government Foreign Borrowing.

Furthermore, F-statistic value of 90.55 and the associated probability value of 0.0000 indicate that the independent variables are jointly significant in explaining economic growth in Nigeria as depicted in Table 4.4. In addition, Rsquare adjusted of 0.9323 pointed out that the model explained about $93.23 \%$ variations in the economic growth while the remaining $6.77 \%$ is accounted for by the stochastic variables. The F-statistic and R-square adjusted figures signify that the model is robust, of goodness fit and reliable in making informed decisions.

The evaluation of the coefficients of the explanatory variables revealed the existence of positive relationship in foreign direct and portfolio investment, workers remittances and foreign borrowing with economic growth as depicted in Table 4.4 and equation 4.1 above. The study further revealed that $0.0035,0.0001$ and 0.0027 probability values of foreign direct and portfolio investment, workers remittances and foreign borrowing respectively are less than the critical probability value of 0.05 . These results infer that the three parameters are significantly related to economic growth in Nigeria. However, there is negative and no significant relationship between foreign aids and economic growth as indicated by its probability value of 0.1470 which exceeds the critical probability value of 0.05 . Therefore, we accept the Hypothesis of no significant relation between foreign aids and economic growth in Nigeria.

\subsection{Results of data analysis (Ghana)}

Table 4.5: Augmented Dickey-Fuller Unit Root Test

\begin{tabular}{|c|c|c|c|c|c|}
\hline Variables & ADF at Levels & ADF Test Statistic & Prob. Values & 5\% Test Critical Values & Decisions \\
\hline RGDP & 7.0704 & 7.0704 & 0.0000 & -2.9862 & \\
\hline FDPI & 1.2644 & -5.7749 & 0.0001 & -2.9980 & \\
\hline FA & -0.3544 & -6.0585 & 0.0000 & -2.9980 & $\mathrm{I}(1)$ \\
\hline WRT & 1.4611 & -4.5900 & 0.0015 & -2.9980 & $\mathrm{I}(1)$ \\
\hline FB & -1.4267 & -4.4413 & 0.0021 & -2.9980 & $\mathrm{I}(1)$ \\
\hline
\end{tabular}

Augmented Dickey-Fuller (ADF) unit root test revealed that only real gross domestic product was stationary at levels. However, foreign direct and portfolio investment, foreign aids, workers remittances and foreign borrowing were stationary at first differencing with the probability value of $0.0001,0.0000,0.0015$ and 0.0021 respectively as shown in table 4.5 above.

Table 4.6: Johansen Co-integration Test

\begin{tabular}{l}
\hline Date: 05/06/14 Time: 13:43 \\
Sample (adjusted): 1986-2012 \\
Included observation: 25 after adjustments \\
Trend assumption: Linear deterministic trend in the data \\
Series: RGDP \\
Exogenous series: FDPI FA WRT FB \\
Warning: Critical values were derived assuming no exogenous series \\
Lags interval (in first difference): 1 to 1 \\
Unrestricted Co-integration Rank Test (Trace) \\
\hline Test \\
\hline Hypothesized Trace 0.05 \\
No. of CE(s) Eigenvalue Statistics Critical Value Prob. ${ }^{* *}$ \\
\hline None 0.010546 0.265042 3.841466 0.6067 \\
\hline Trace test indicates no Co-integration at the 0.05 level \\
*denotes rejection of the hypothesis at the 0.05 level \\
***ackinnon-Haug-Michelis (1999) p-values \\
Unrestricted Co-integration Rank Test (Maximum Eigenvalue) \\
\hline Hypothesized Max-Eigen 0.05 \\
No. of CE(s) Eigenvalue Statistics Critical Value Prob. ${ }^{* *}$ \\
\hline None 0.010546 0.265042 3.841466 0.6067 \\
\hline
\end{tabular}




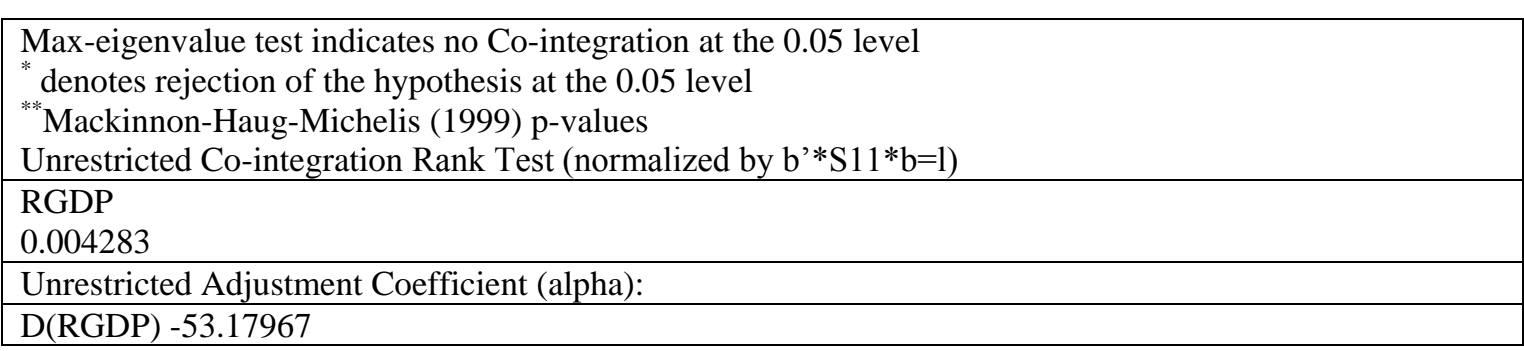

Table 4.6 showed that at $5 \%$ critical value (3.841466) is greater than the Trace Statistic and Maximum Eigenvalue Statistic (0.265042) and probability values of 0.6067 respectively with no co-integrating equation. This is an indication of no co-integrating equation and therefore necessitated the acceptance of the null hypothesis of no co-integration among the variables.

Table 4.7: Granger Causality Test

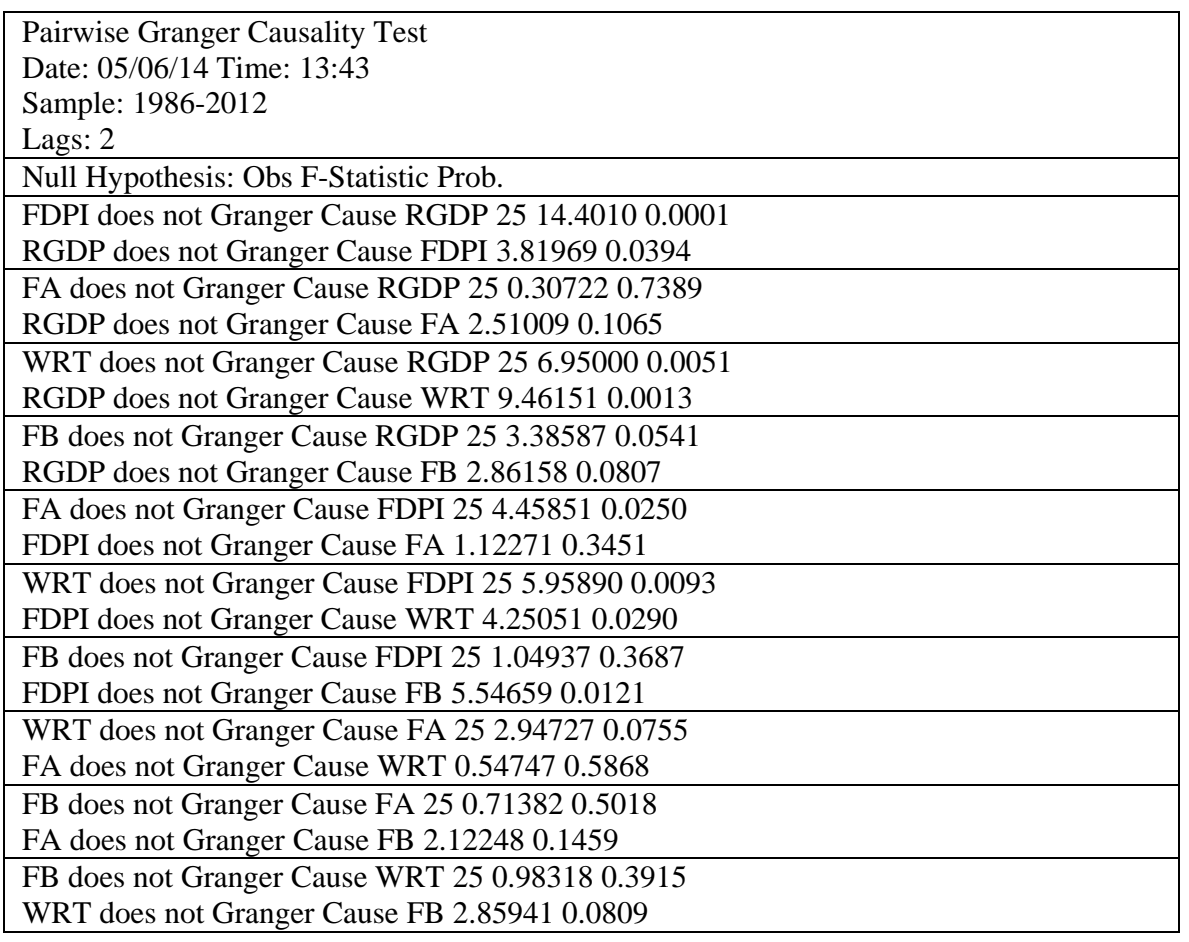

\section{Table 4.8: Results of Regression Analysis}

Dependent Variable: RGDP

Method: Least Squares

Date: 05/06/14 Time: 11:10

Sample: 1986-2012

Included observations: 27

\begin{tabular}{ccccc}
\hline \hline \multicolumn{1}{c}{ Variable } & Coefficient & Std. Error & t-Statistic & Prob. \\
\hline \hline C & 4059.445 & 462.1165 & 8.784462 & 0.0000 \\
FDPI & 0.624715 & 0.208312 & 2.998932 & 0.0066 \\
FA & 0.204985 & 0.781553 & 0.262279 & 0.7955 \\
WRT & 49.01716 & 6.594086 & 7.433504 & 0.0000 \\
FB & 0.299690 & 0.059881 & 5.004750 & 0.0001 \\
\hline \hline & & & \\
R-squared & 0.979582 & Mean dependent var & 9055.494 \\
Adjusted R-squared & 0.975870 S.D. dependent var & 3774.545 \\
S.E. of regression & 586.3308 Akaike info criterion & 15.75122 \\
Sum squared resid & 7563245 . Schwarz criterion & 15.99119 \\
Log likelihood & -207.6415 Hannan-Quinn criter. & 15.82258 \\
F-statistic & 263.8749 Durbin-Watson stat & 1.657493 \\
Prob(F-statistic) & 0.000000 & & \\
\hline \hline
\end{tabular}


Four explanatory variables were regressed against the dependent variable - Real Gross Domestic Product, the model is as stated below:

$$
\mathrm{RGDP}_{\mathrm{t}}=4059.445+0.625 \mathrm{FDPI}+0.205 \mathrm{FA}+49.017 \mathrm{WRT}+0.30 \mathrm{FB}
$$

(8.7845) (2.9989) (0.2623) (7.4335) (5.0048)

\section{NB: the t-values are in parentheses}

The result of the regression revealed according to Table 4.8, that a million Dollar increase in real gross domestic product will attract 0.625 million Dollars of foreign direct and portfolio investment, 0.205 million Dollars increase in foreign aids, 49.017 million Dollars increase in workers remittances and 0.3 million Dollars increase in foreign borrowings in Ghana.

Moreover, the F-statistic value of 263.87 and the associated probability value of less than $1 \%$ indicate that the explanatory variables are jointly significant in explaining economic growth in Ghana. Also, R-square adjusted of 0.976 implies that the explanatory variables jointly explained about $97.6 \%$ variations in economic growth while the remaining $2.4 \%$ of economic growth is accounted for by the error term. The F-statistic and R-square adjusted figures signify that the model is robust and goodness of fit in making reliable decisions.

Furthermore, the evaluation of the coefficients of the explanatory variables revealed the existence of positive relationship between economic growth and all the explanatory variables as depicted in table 4.8 and equation 4.2 above. The regression result additionally revealed that the probability values of foreign direct and portfolio investment $(0.0066)$, workers remittances $(<0.01)$ and foreign borrowing $(0.0001)$ are respectively less than the critical probability value of $5 \%$. These results depict that these variables are significantly related to economic growth of Ghana. Consequently, we conclude that foreign direct and portfolio investments, workers' remittances and foreign borrowing respectively impacted significantly on economic growth of Ghana. However, we accept the hypothesis "there is no significant relationship between foreign aids and economic growth in Nigeria", since its probability value of 0.7955 is greater than the critical probability value of 0.05 . Finally, the Durbin Watson value of 1.6575 is close to 2 indicating that there is slight presence of serial correlation among the variables.

\subsection{Results of data analysis (India)}

Table 4.9: Augmented Dickey-Fuller Unit Root Test

\begin{tabular}{|c|c|c|c|c|c|}
\hline Variables & ADF at Levels & ADF Test Statistic & Prob. Values & 5\% Test Critical Values & Decisions \\
\hline RGDP & 8.7039 & 8.7039 & 0.0000 & -2.9862 \\
\hline FDPI & 1.5449 & -5.4810 & 0.0002 & -3.0049 \\
\hline FA & -2.8673 & -5.8682 & 0.0001 & -3.0049 & -2.9981 \\
\hline WRT & 2.5760 & -2.9981 & 0.0229 & -2.9919 & $\mathrm{I}(1)$ \\
\hline FB & 3.9938 & 3.9938 & 0.0000 & $\mathrm{I}(1)$ & $\mathrm{I}(0)$ \\
\hline
\end{tabular}

Applying Augmented Dickey-Fuller (ADF) unit root test in examining the properties of time series data as tabulated in 4.9 above, that Real Gross Domestic Product and Foreign Borrowing are stationary at levels with probability value of 0.0000 respectively, while Foreign Direct and Portfolio Investments, Foreign Aids and Workers Remittances were stationary at first differencing with the following probabilities: $0.0002,0.0001$ and 0.0229 .

Table 4.10 showed that at 5\% critical value (3.841466) is greater than the Trace Statistic and Maximum Eigenvalue Statistic (0.352686) and probability values of 0.5526 respectively. This is an indication of no co-integrating equation and therefore necessitated the acceptance of the null hypothesis of no Co-integration among the variables. 
Chigbu Ezeji E., Ubah Chijindu Promise, Chigbu Uzoamaka S.

Impact of Capital Inflows on Economic Growth of Developing Countries

Table 4.10 Johansen Co-integration Test

Date: 05/06/14 Time: 13:45

Sample (adjusted): 1986-2012

Included observation: 25 after adjustments

Trend assumption: Linear deterministic trend in the data

Series: RGDP

Exogenous series: FDPI FA WRT FB

Warning: Critical values were derived assuming no exogenous series

Lags interval (in first difference): 1 to 1

Unrestricted Co-integration Rank Test (Trace)

Test

Hypothesized Trace 0.05

No. of CE(s) Eigenvalue Statistics Critical Value Prob. ${ }^{* *}$

None 0.0140080 .3526863 .8414660 .5526

Trace test indicates no Co-integration at the 0.05 level

* denotes rejection of the hypothesis at the 0.05 level

*** Mackinnon-Haug-Michelis (1999) p-values

Unrestricted Co-integration Rank Test (Maximum Eigenvalue)

Hypothesized Max-Eigen 0.05

No. of CE(s) Eigenvalue Statistics Critical Value Prob. ${ }^{* *}$

None 0.0140080 .3526863 .8414660 .5526

Max-eigenvalue test indicates no Co-integration at the 0.05 level

${ }^{*}$ denotes rejection of the hypothesis at the 0.05 level

*** Mackinnon-Haug-Michelis (1999) p-values

Unrestricted Co-integration Rank Test (normalized by b ${ }^{*} \mathrm{~S} 11 * \mathrm{~b}=1$ )

RGDP

3.39E-05

Unrestricted Adjustment Coefficient (alpha):

D(RGDP) 3588.403

Table 4.11: Granger Casualty Test

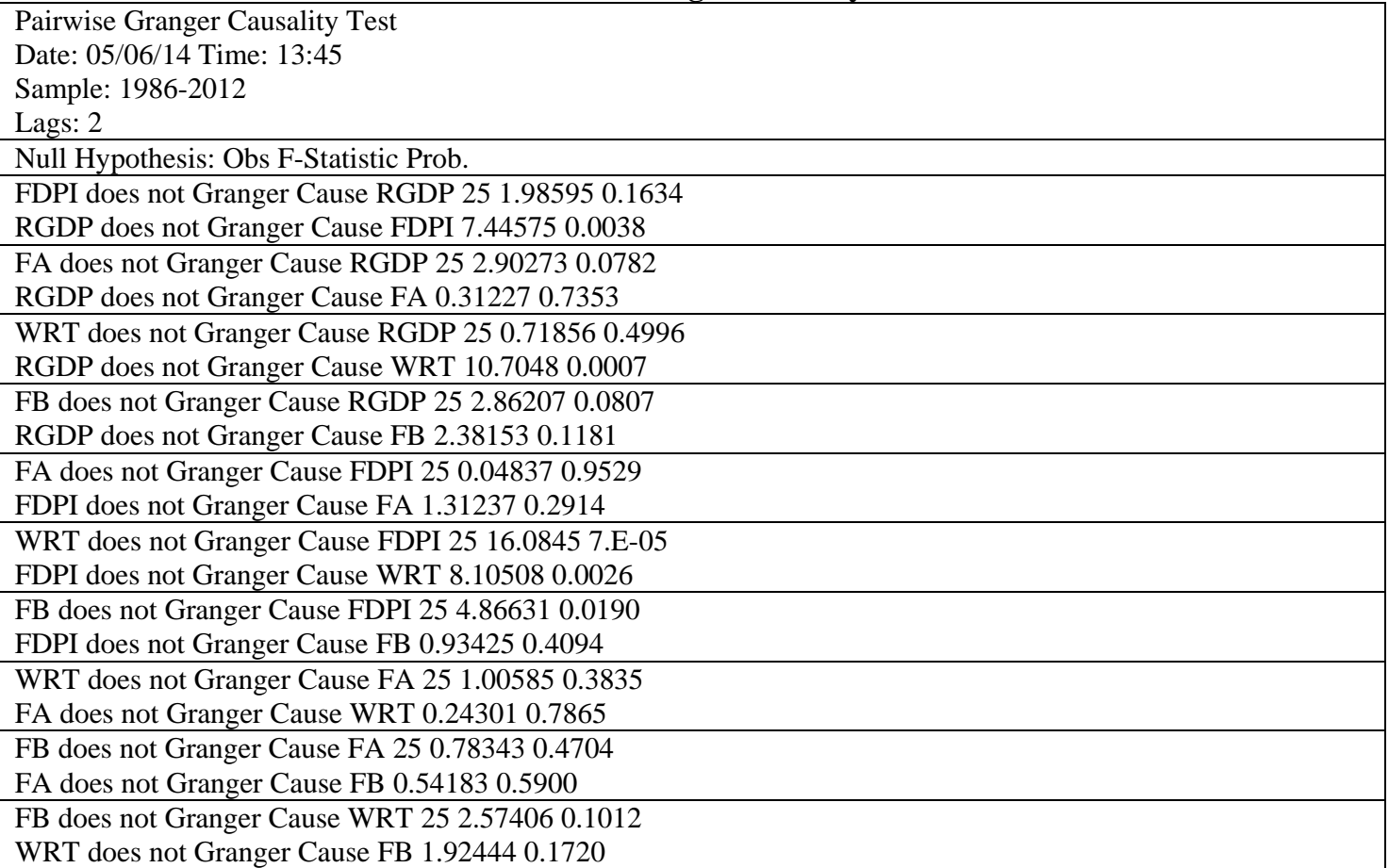

The results of the Granger Causality test showed that there are bi-directional causal relationship exist only between Workers Remittances and Foreign Direct and Portfolio Investment in agreement with Table 4.1. One directional causal relationship exists from Real Gross Domestic Product to Foreign Direct and Portfolio Investment; Real Gross Domestic Product to Workers Remittances; Foreign Borrowing to Foreign Direct and Portfolio Investment. However, no causal relationship exist between Foreign Aids and Real Gross Domestic Product; Foreign Borrowing and Real Gross Domestic Product; Foreign Aids and Foreign Direct and Portfolio Investment; Workers Remittances and Foreign Aids; Foreign Borrowing and Foreign Aids and Foreign Borrowing and Workers Remittances. 
Chigbu Ezeji E., Ubah Chijindu Promise, Chigbu Uzoamaka S.

Impact of Capital Inflows on Economic Growth of Developing Countries

Table 4.12: Results of Regression Analysis

Dependent Variable: RGDP

Method: Least Squares

Date: 05/06/14 Time: 11:08

Sample: 1986-2012

Included observations: 27

\begin{tabular}{crrrr}
\hline \hline \multicolumn{1}{c}{ Variable } & Coefficient & Std. Error & t-Statistic & Prob. \\
\hline \hline C & 61942.02 & 5882.467 & 10.52994 & 0.0000 \\
FDPI & 0.134621 & 1.210914 & 0.111173 & 0.9125 \\
FA & -4.271482 & 2.759353 & -1.548001 & 0.1359 \\
WRT & 1.512552 & 0.343001 & 4.409759 & 0.0002 \\
FBI & 0.076871 & 0.096054 & 0.800292 & 0.4321 \\
\hline \hline R-squared & 0.969283 Mean dependent var & 93765.34 \\
Adjusted R-squared & 0.963699 S.D. dependent var & 36591.33 \\
S.E. of regression & 6971.720 Akaike info criterion & 20.70269 \\
Sum squared resid & $1.07 E+09$ Schwarz criterion & 20.94266 \\
Log likelihood & -274.4863 Hannan-Quinn criter. & 20.77404 \\
F-statistic & 173.5564 Durbin-Watson stat & 0.747697 \\
Prob(F-statistic) & 0.000000 & & \\
\hline \hline
\end{tabular}

Four variables were regressed against the independent variable - Real Gross Domestic Product, the model is as stated below:

$$
\mathrm{RGDP}_{\mathrm{t}}=61942+0.135 \mathrm{FDPI}-4.271 \mathrm{FA}+1.513 \mathrm{WRT}+0.077 \mathrm{FB} .
$$

(10.5299) (0.1112) (-1.5480) (4.40976) (0.8003)

$N B$ : the $t$-values are in parentheses

The results of the regression showed that a million Dollar increase in real gross domestic product will cause 0.135 increase in foreign direct and portfolio investment, 4.271 Dollar decrease in foreign aids, 1.513 Dollar increase in workers remittances and 0.077 million Dollar increase in foreign borrowing. The result further uncovered that Fstatistic value of 173.556 with associated probability value of less than $1 \%$ is an indication that the joint statistical significance hypothesis of the model cannot be rejected. Also, R-square adjusted value of 0.964 implied that the explanatory variables model jointly explained about $96.4 \%$ of the variations in economic growth while the remaining $3.6 \%$ variations in economic growth is accounted for by error term. The F-statistic and R-square adjusted figures jointly signify that the model is robust and significant in making reliable decisions in India. More so, the evaluation of the contribution to significance of the model by each of the explanatory variables revealed that foreign direct and portfolio investment, foreign aids and foreign borrowing are not statistically significant in explaining economic growth in India as depicted by their respective probability values of $0.9125,0.1359$ and 0.4321 exceed the critical probability value of 0.05. On the other hand, workers' remittances significantly affect economic growth of India judging from their probability value of 0.0002 less than 0.05 critical probability value. 
Chigbu Ezeji E., Ubah Chijindu Promise, Chigbu Uzoamaka S.

Impact of Capital Inflows on Economic Growth of Developing Countries

Table 4.13: Statistical table for comparative analysis for Nigeria, Ghana and India

\begin{tabular}{|c|c|c|c|c|c|c|c|c|c|}
\hline Country & $\begin{array}{l}\text { Statistical } \\
\text { indicators }\end{array}$ & FDPI & FA & WRT & FB & $\begin{array}{c}\text { Constan } \\
t\end{array}$ & $\begin{array}{c}\text { F- } \\
\text { statisti } \\
\text { c }\end{array}$ & $\mathbf{R}^{2}$ & $\overline{D W}$ \\
\hline NIGERIA & $\begin{array}{l}\beta \text { coefficients } \\
\text { t-statistic } \\
\text { p-values }\end{array}$ & $\begin{array}{c}4.488 \\
0 \\
3.309 \\
5 \\
0.003 \\
5\end{array}$ & $\begin{array}{c}- \\
1.4906 \\
- \\
1.5033 \\
0.1470\end{array}$ & $\begin{array}{c}5.421 \\
6 \\
5.000 \\
2 \\
0.000 \\
1\end{array}$ & $\begin{array}{c}1.770 \\
7 \\
3.374 \\
7 \\
0.002 \\
7\end{array}$ & $\begin{array}{c}11105.24 \\
0.6708 \\
0.5093\end{array}$ & $\begin{array}{c}90.55 \\
0.0000\end{array}$ & $\begin{array}{c}0.932 \\
3\end{array}$ & 1.3627 \\
\hline GHANA & $\begin{array}{l}\beta \text { coefficients } \\
\text { t-statistic } \\
\text { p-values }\end{array}$ & $\begin{array}{c}0.624 \\
7 \\
2.998 \\
9 \\
0.006 \\
6\end{array}$ & $\begin{array}{l}0.2050 \\
0.2623 \\
0.7955\end{array}$ & $\begin{array}{c}49.01 \\
7 \\
7.433 \\
5 \\
0.000 \\
0\end{array}$ & $\begin{array}{c}0.299 \\
7 \\
5.004 \\
8 \\
0.000 \\
1\end{array}$ & $\begin{array}{c}4059.445 \\
8.7845 \\
0.0000\end{array}$ & $\begin{array}{l}263.87 \\
0.0000\end{array}$ & $\begin{array}{c}0.975 \\
9\end{array}$ & 1.657 \\
\hline INDIA & $\begin{array}{l}\beta \text { coefficients } \\
\text { t-statistic } \\
\text { p-values }\end{array}$ & $\begin{array}{c}0.134 \\
6 \\
0.111 \\
2 \\
0.912 \\
5\end{array}$ & $\begin{array}{c}- \\
4.2715 \\
- \\
1.5480 \\
0.1359\end{array}$ & $\begin{array}{c}1.512 \\
6 \\
4.409 \\
8 \\
0.000 \\
2\end{array}$ & $\begin{array}{c}0.076 \\
9 \\
0.800 \\
3 \\
0.432 \\
1\end{array}$ & $\begin{array}{c}61942.02 \\
10.5299 \\
0.0000\end{array}$ & $\begin{array}{l}173.56 \\
0.0000\end{array}$ & $\begin{array}{c}0.963 \\
7\end{array}$ & 0.7477 \\
\hline
\end{tabular}

Source: Least Square Results for the three Countries

\section{Discussion of results}

The findings of this study showed that capital inflows contributed significantly in the economic growth of the three countries, but the strength of their contributions marginally increased from Nigeria, India and Ghana respectively. This is depicted in table 4.13 above as the joint variations of the predicting variables explained $93.2 \%, 96.4 \%$ and $97.6 \%$ of economic growth in Nigeria, India and Ghana respectively. This result is validated with the values of F-statistic of Nigeria (90.55), India (173.56) and Ghana (263.87) which followed the same progression indicating that explanatory variables jointly have significant impact on the economic growth of the three countries.

The significant and positive relationship of foreign direct and portfolio investment in Nigeria as showed in table 4.13 above $(\mathrm{t}$-value $=3.3095$, $\mathrm{p}$-value $=0.0035)$ is in line with the a priori expectation of this study as it is supported by the previous reports of Ogundipe and Aworinde (2011), Rachidi and Saidi (2011) and Tiwari and Mutascu (2011). This finding is typically true as there are evidences of huge foreign investment in the oil and gas sector, communication sector among others by renowned multinationals in Nigeria. In addition, the liberalization policy of 1986 and the consolidation of the banking sub-sector of 2004, which resulted to a boom in the Nigeria capital market, are also relevant to this finding. This result is also the same for Ghana $(t-v a l u e=2.9989$, $p$-value $=0.0066)$ as tabulated in 4.13 above. It revealed that foreign direct and portfolio investment is positively and significantly related to her economic growth. This might be unconnected to recent divestment of foreign investment from Nigeria to Ghana, foreign investment in her agricultural sector (cocoa production) and recent oil discovery and exploration by multinational corporations. In addition, there are indications of enabling environment and political stability that will encourage investments to thrive in Ghana. This result is different in India as the variable was found insignificant in explain economic growth.

Foreign aids were negatively related to economic growth in Nigeria and India as showed with their individual coefficients of -1.4906 and -4.2715 in table 4.13 above. This result is in variance with our a priori expectation as well as previous studies (Sakyi, 2010 and Karras, 2006). This may be an indication that foreign aids might have not been channeled to the productive ventures in both countries. However, some findings revealed that foreign aids distorts the domestic income distribution and encourages inefficient and corrupt government in developing countries (Griffin and Enos, 1970).

Citizens of many developing economies leave the shore of their home countries to foreign countries in search of greener pastures, which they may not find domestically. They engage in different kinds of business and labors to make a living and repatriate others to home countries, which are always invested in education, trade, real estate, equity portfolios etc. These is obviously in connection with the findings of this study as well as Newland and Patrick (2004), as workers' remittances were found to be positively and significantly related to the respective economic growth of the three countries. Specifically this finding supports the claim that Indian economy depends largely on the earnings from labor capital that is exported to the rest of the world. 
Lastly, government borrows from the international market to finance her economic activities, infrastructural development and budget deficit especially when there is savings - investment deficit in the domestic market. This study revealed that foreign borrowings positively impacted on the economic growth of Nigeria, Ghana and India but significant only in Nigeria and Ghana as shown in table 4.13 above. This significant impact in Nigeria and Ghana could be related to the debt forgiveness by London and Paris Clubs and other foreign agencies which have freed funds used in servicing the debts to other viable ends in the economy. Furthermore, both countries may have invested their external borrowed funds wisely and productively.

\section{Conclusions and recommendations}

The impact of capital inflows on economic growth can never be over emphasized. This study investigated this with interesting results as discussed earlier. The collective impacts of the explanatory variables on economic growth were found to be significant though not all were significant individually.

So far, the results suggest that developing economies depend so much on foreign capital inflows for their growth at the expense of their local opportunities as seen in the findings above. A country like Nigeria where the economic growth have been induced by foreign investment have not given good account of herself since this growth have not been noticed on the real sector of the economy as high rate of unemployment, poor standard of living, poor quality of education, inequality, high mortality rate as well as infrastructural decay still dominate the economy. Other source of capital like the capital market, government expenditure remains veritable in closing the resource gap of developing economies. At the same time, economic diversification as well as a better enabling environment for foreign investment to thrive is also inevitable. Going by the findings of this study, the following recommendations were made to improve the contribution of capital inflows in economic growth of developing economies specifically Nigeria, Ghana and India:

- Developing economies should attract more of foreign direct and portfolio investments and borrow more for the purpose economic growth.

- Developing countries should make their economies investment friendly since foreign investments have tendency of growing their economies.

- Workers remittances should be encouraged in developing economies.

- Governments of developing countries should make policies that will make local investments to thrive so as to complements foreign capital inflows.

- Foreign aids should be channeled to productive ends to contribute to economic growth in the developing countries.

\section{References}

- Adeniyi, O., Omisakin, O., Egwaikhide, F.O. and Oyinlola, A. (2012), "Foreign Direct Investment, Economic Growth and Financial Sector Development in Small Open Developing Economies", Economic Analysis and Policy, Vol. 42 No. 1.

- Aurangeb and Haq A. (2012), "Impact of Foreign Capital Inflows on Economic Growth in Pakistan", European Journal of Economics, Finance and Administrative Sciences ISSN 1450-2275 Issue 46. www.eurojournals.com/EJEFAS.htm.

- Boskovska D. (2006), "The Role of the Foreign Capital in the Integration Process of Republic of Macedonia", The Amfiteatru Economic Journal Vol. 8, pp.114-121.

- Caves, R.E. (1971), "International Corporations: The Industrial Economics of Foreign Investment", Economica, XXXIII, pp.5-6

- Chatterjee, S. and Turnosky S.J. (2005), “Foreign Aid and Economic Growth: The Role of Flexible Labour Supply": A Paper Presented at the Annual Conference of the Royal Economic Society in Swansea.

- Dunning, J.F. (1993), The Globalisation of Business, London: Routledge.

- Dunning, J.F. (1980), "Towards and Ecletic Theory of International Production, Journal of International Studies, Vol. XI, pp.9-31.

- Edwards, S. (2004), "Financial Openness, Sudden Stops and the Current Account Reversal", Economic Review, Vol. 94, pp. 59-64.

- Ekeocha, P. C., Ekeocha, C. S., Malaolu, V. and Oduh, M. O. (2012), "Modelling the Long Run Determinants of Foreign Portfolio Investment in Nigeria", Journal of Economics and Sustainable Development, Vol.3, No.8. www.iiste.org.

- Engle, R.F. and Granger, C. W. J. (1987), “Co-integration and Error Correction: Representation, Estimation and Testing", Econometrica, Vol.55, pp.251-276.

- Ezeabasili, V. N. Isu, H.O. and Mojekwu J.N. (2011), "Nigeria’s External Debt and Economic An Error Correction Approach", International Journal of Business and Management Vol. 6, No.5. www.ccsenet.org/ijbm. 
- Fambon, S. (2013), "Foreign capital inflow and economic growth in Cameroon", WIDER Working Paper No.2013/124.

- Griffin, K.B. and Enos, J.L. (1970), "Foreign Assistance; Objectives and Consequences", Economic Development and Cultural Change, Vol. 18, No. 3, pp. 313-327.

- Gupta, K.L. (1970), "Foreign Capital and Domestic Savings: A Test of Haavelmo’s Hypothesis with Cross Country Data: Review of Economics and Statistics, Vol. 52, No. 2, pp. 214-216.

- Hood N. and Young S. (1979), The Economics of Multinational Enterprises, London: Longman pp.44-86.

- Hymer, S.H. (1976), The Internattional Operations of National Firms: A Study of Direct Investment, Cambridge MIT, Press.

- Karin M. (2009), "Optimal Deficit and Debt in the Presence of Foreign Aid, World Development, Vol.38, No.1, pp.19-27.

- Karras, G (2006), “ Foreign Aid and Longrun Economic Growth: Empirical Evidence for Panel of Developing Countries”, Journal of International Development Vol. 18, 15-26.

- Kemp, M.C. (1964), The Theory of International Trade, Ithaca: Prentice- Hall, pp.13-14.

- Lensink, R and Morrissey O. (2001), "Aid Instability as a measure of Uncertainty and the Positive Impact of AID on Growth", Journal of Development Studies, Vol. 36, No. 3, pp.31-49.

- Levine, R. (2001), "International Financial Liberalization and Economic Growth", Review of International Economics, Vol. 9, pp.668-702.

- Macdougall, G.D.A. (1958), “The Benefits and Costs of Private Foreign Investment Abroad: A theoretical approach”, Economic Record, XXXVI, pp.13-35.

- Narayan, S. (2013), Causal Relationship between Foreign Capital Inflows and Economic Growth: Empirical Evidence from India", International Journal of Economics, Finance and Management, $\quad$ Vol.2, No.1. www.ejournalofbusiness.org.

- Obiechina, M.E and Ukeje E.U. (2013), "Economic Growth, Capital Flows, Foreign Exchange Rate, Export and Trade Openness in Nigeria", International Journal of Economics and Management Sciences, Vol.2, No.9, pp.01-13. managementjournal.org

- $\quad$ Odhiambo, N.M. (2011), "Financial Deepening, Capital Inflows and Economic Growth Nexus in Tanzania: A Multivariate Model", Journal of Social Sciences, Vol.28, No.1, pp.65-71.

- Olusanya, S.O. (2013), "Impact of Foreign Direct Investment Inflow on Economic Growth in a Pre and Post Deregulated Nigeria Economy: A Granger Causality Test", European Scientific Journal, vol.9,

No. 25.

- Over, A.M. (1975), "An Example of Simultaneous Equations Problems: A Note on Foreign Assistance:

Objectives and Consequences", Economic Development and Cultural Change, Vol. 23, $\quad$ No. 4, pp.751-756.

- Pesaran M., Shin Y. and Smith R. (2001), "Bounds Testing Approaches to the Analysis of Level Relationships", Journal of Applied Econometrics, Vol.16, pp.289-326.

- Razin, A. and Sadka, E. (2001), "Country Risk and Capital Flow Reversals" Economic Letters, Vol. 72, pp.73-77.

- Sakyi, D. (2011), "Trade Openess, Foreign Aid and Economic Growth in Post Liberation Ghana: An Application of ARDL Bounds Test”. Journal of Economic and International Finance, Vol. 3, No. 3, pp.146-156. www.academicjournals.org/JEIF.

- Umoh, O.J., Jacobs, A.O. and Chuku, C.A. (2012), "Foreign Direct Investment and Economic Growth in Nigeria: An Analysis of the Endogenous Effects", Current Research Journal of Economic Theory, Vol. 4, No.3, pp.53-66. 